\title{
Inheritance of Resistance to Blotchy Ripening in Processing Tomatoes
}

J . A . D i c k

Nabisco Brands (Canada) Ltd., 759 Wellington Street, Dresden, Ont. NOP 1M0, Canada

\author{
V.I. Shattuck \\ Department of Horticultural Sciences,. University of Guelph, Guelph, Ont. N1G 2W1, Canada \\ Additional index words. Lycopersicon esculentum, diallel analysis, combining ability, gene action
}

\begin{abstract}
Inheritance of resistance to blotchy ripening In tomato (Lycopersicon esculentum Mill.) cultivars intended for machine harvest was studied in two diallel crosses using the Hayman and Griffing analyses. Additive effects were most important as indicated by the high level of general combining ability compared with specific combining ability. Some hybrids performed better than the mid-parent mean; however, heterosis for resistance to blotch above the best inbred line was not evident. Epistasis occurred between recessive genes in two parents, resulting in reduced blotch. No significant interaction between the expression of blotch in diallel progeny and $\mathbf{K}$ availability was evident. Genotypeenvironment Interaction was significant, but relative variation in blotch between experiments only occurred in cultivars with an intermediate level of resistance.
\end{abstract}

Blotchy ripening (blotch) is a tomato fruit ripening disorder that has also been described as cloud, graywall, and waxy patch. Hobson and Davies (1977) described the basic physical symptom of blotch as areas of imperfectly ripened tissue that may or may not be visible on the exterior of the fruit. The most severely affected area is next to the calyx and on the shoulders. The discolored area remains firmer than the surrounding red tissue and does not ripen normally, The specific symptoms of blotch on processing cultivars intended for machine harvest and used in this study consisted of hard yellow or yellowish-green pericarp tissue radiating from the stem scar following the pattern of vascular tissue. In fruit affected severely, yellow tissue was visible externally, but in most cases the exterior of the fruit appeared normal, because symptoms were masked by a thin layer of normally pigmented cells just under the epidermis. Differences in the expression of blotch in processing tomato lines are more apparent at low than at moderate or high levels of $\mathrm{K}$ in the soil (Dick and Shattuck, 1986). All of the cultivars used in this study had the uniform ripening gene $(\mathrm{u})$; cultivars lacking this gene are susceptible to a severe form of blotchy ripening called yellow shoulder, or yellow top.

Blotch results in serious economic losses to the tomato wholepack processing industry due to increased labor costs and decreased recovery of pulp. Blotchy fruit must be removed by hand after peeling (Fig. 1) because blotch is not completely visible externally. Fruit exhibiting blotch symptoms in $\geq 25 \%$ of the shoulder tissue are unusable for whole-pack production (Canada Agricultural Products Standards Act, 1968). If caustic peeling is used, $23 \%$ of the fruit weight is lost (Smith et al; 1988). Although blotchy, peeled fruit can be used for pulp, such peeling losses cannot be recovered. Marginal blotchy fruit may be canned, but product quality is adversely affected.

Blotch is influenced by K nutrition (Besford and Maw, 1975; Dick and Shattuck,. 1986; Picha rind Hall, ,1981; Winsor and Long, 1967), moisture (Berry, 1966; Van der Boon, 1973), temperature (White, 1938), solar radiation (Lipton, 1970; Hornby and Matsumoto; 1974) and biotic factors (Boyle and Bergman, 1967; Mokhtar et al., 1982). Cultivar differences in blotch sus-

Received for publication 6 Mar. 1989. The cost of publishing this paper was defrayed in part by the payment of page charges. Under postal regulations, this paper therefore must be hereby marked advertisement solely to indicate this fact. ceptibility have been reported (Minges, 1973; Dick and Shattuck, 1986; Picha and Hall, 1981), but limited information exists on the genetic control of this disorder (Fogelman, 1966).

The purpose of this investigation was to study the inheritance of blotchy ripening in several processing tomato cultivars in order to provide information for effective selection against this disorder.

\section{Materials and Methods}

Experiment 1. A nine-parent half-diallel was conducted in 1985 using cultivars from Nabisco Brands Ltd. (7223, 7280, 7600, 7713, 8430, 8754), Campbell Soup Co. (C37A, C38), and H.J. Heinz (H722) that varied in blotch susceptibility. A half-diallel design was chosen because a preliminary study in 1984 involving lines 7223, 7280, 7713, 8430, and 8754 revealed the absence of maternal differences for blotch susceptibility (Dick, 1988). Seeds of each cultivar were planted in a growth chamber and crosses were made in all combinations to produce $F_{1}$ seed. Six-week-old parental and $F_{1}$ transplants grown in a greenhouse were planted on a Brookston silt loam soil of $\mathrm{pH}$ 7.1. This site was selected because of a low (117 ppm) available $\mathrm{K}$ level assessed using the ammonium acetate extraction procedure (Chapman and Pratt, 1961). Before planting, $\mathrm{NH}_{4} \mathrm{NO}_{3}$ was broadcast at $100 \mathrm{~kg} \cdot \mathrm{ha}^{-1}$ and triple superphosphate was applied according to soil tests (Ontario Ministry of Agriculture and Food, 1985).

Each treatment consisted of a single row $6 \mathrm{~m}$ long $\times 1.5 \mathrm{~m}$ wide. Plants were spaced $30 \mathrm{~cm}$ apart within rows, resulting in a plant density of 22,222 plants/ha. The experimental design was a randomized complete block with eight replications. Of the 20 plants in each plot, only the inner four plants were used for data collection.

The plots were harvested by hand when $\geq 75 \%$ of the fruit were ripe, to simulate the time when commercial machine harvesting would start. Ripe fruit were sliced transversely at the stem end and 3 to $6 \mathrm{~mm}$ of flesh was removed to expose the inner shoulder tissue where blotch symptoms are most clearly expressed. Tomatoes with $>25 \%$ blotchy area in the shoulder tissue were classified as blotchy. To assure consistency during the evaluation, each fruit was compared against photographic standards (Fig. 2). The percent blotchy fruit (percent blotch) for each plot was obtained by dividing the weight of blotchy fruit by the total weight of ripe fruit. 


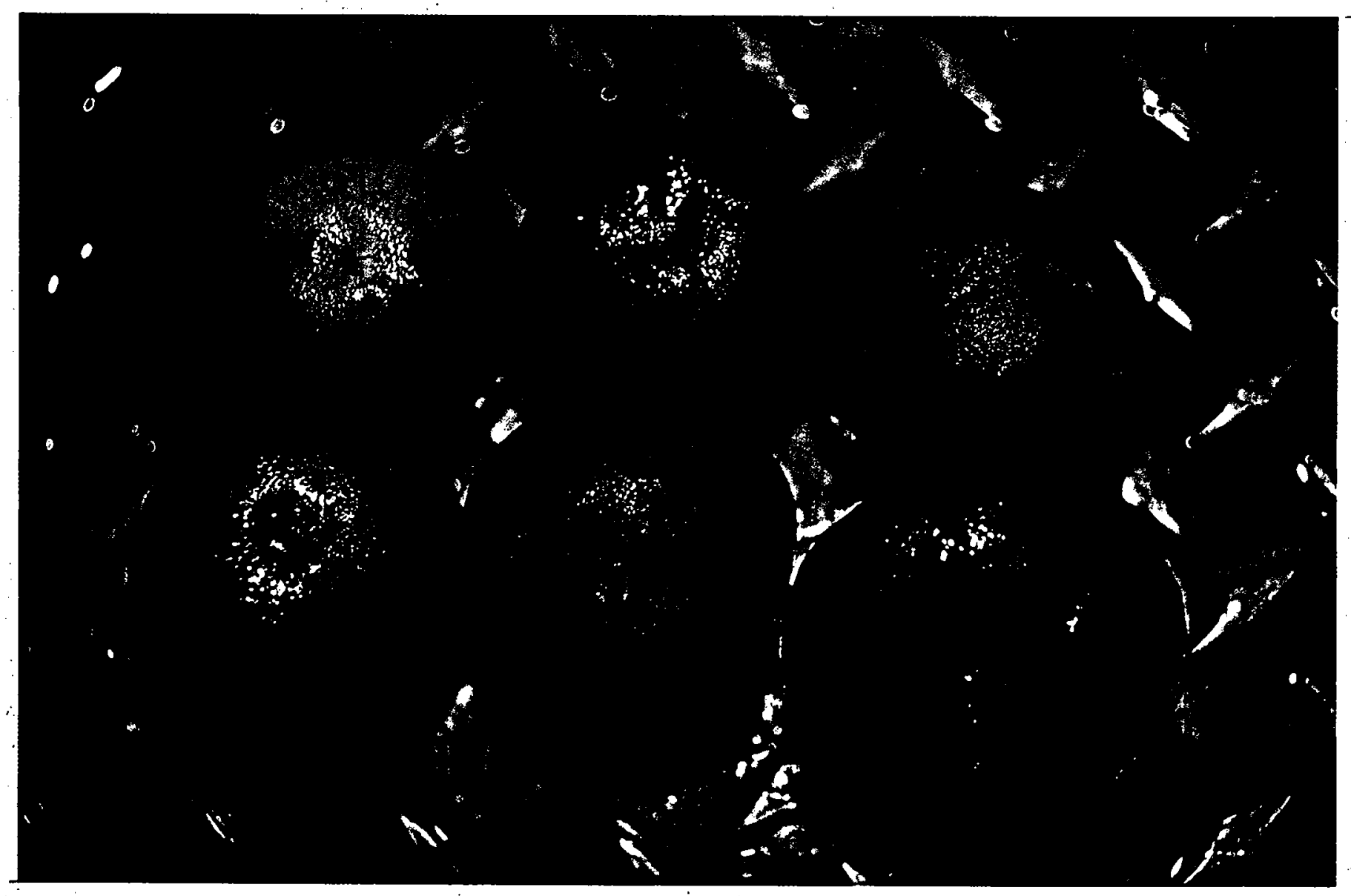

Fig. 1. Blotchy and non-blotchy tomatoes after lye-peeling. In top row, left and right fruits are blotchy; in bottom row, middle fruit is blotchy.

Experiment 2. A nine-parent half-diallel was conducted in 1986 using cultivars 6729, 7223, 7713, 8430, 8754, H722, H2653, Ohio 7814, and ST64. H2653, Ohio 7814, and ST64, and 6729 were developed by H.J. Heinz, Ohio State Univ., Agriculture Canada, and Nabisco, respectively. Parental and $F_{1}$ transplants were planted on a Brookston silt loam soil of $\mathrm{pH}$ 7.4. Before planting; four of the eight replications were fertilized with $200 \mathrm{~kg} \mathrm{~K} \mathrm{~K}_{2} \mathrm{O} / \mathrm{ha}$. Soil samples taken 8 weeks after planting from each plot revealed soil K levels of 59 and $48 \mathrm{ppm}$ in the fertilized and unfertilized replicates, respectively. This represents a very low level of available $\mathrm{K}$ for processing tomatoes (Widders and Lorenz, 1982; Dick, 1988). Methods for this experiment were the same as those for Expt. 1.

Statistical analysis. Data on the percentage of fruit with blotch were initially tested for homogeneity of variance and the arcsin transformation was applied (Steel and Torrie, 1980). Analysis of variance (ANOVA) was performed to determine the presence of genotypic differences. Data from the diallel crosses were analyzed using the methods of Hayman (1954) and Griffing (1956). Broad- and narrow-sense heritabilities were determined using the method of Mather and Jinks (1982). A computer program (Christie et al., 1988) was developed and used to perform all calculations for the ANOVA, Hayman, and Griffing analyses.

General (GCA) and specific (SCA) combining abilities were calculated using Griffing's Model 1, Method II (Griffing, 1956). Model 1 assumes all effects are fixed so valid inferences apply only to the parents used in the diallel cross. In Method II, the parents and only one set of $F_{1}$ progeny are included in the experiment (no reciprocal crosses).

\section{Results}

The ANOVA of parental and $\mathrm{F}_{1}$ progenies for both experiments revealed highly significant differences for percent blotch among genotypes (Table 1). In Expt. 1, lines 7280 and 8430 were the most blotch-resistant and 7600 and 7713 were the most susceptible (Table 2). In Expt. 2, 8430 and ST64 were the most blotch-resistant, while H2653 was the most susceptible (Table 3).

In the Hayman analysis of Expt. 1, regression of parent-, offspring covariances $(\mathrm{Wr})$ on array variances $(\mathrm{Vr})$ revealed that the slope of the regression deviated significantly from 1.0 ( $b=$ $0.24 \pm 0.17)$, suggesting nonallelic interaction. In the $\mathrm{Wr} / \mathrm{Vr}$ graph of the complete diallel, both 7600 and 7713 deviated substantially from the other array points (Fig. 3). When either 7713 or 7600 was eliminated from the diallel and the resulting $8 \times 8$ diallel analyzed, the slope of the regression of $\mathrm{Wr}$ on Vr did not differ significantly from 1 (Table 1). Deletion of 7713 resulted in significance of $\mathrm{F}$, implying unequal gene frequencies. This possibly resulted from the influence of 7600 ; since deletion of 7600 resulted in equal gene frequencies. When 7713 and 7600 were, both eliminated from the diallel, the Hayman analysis remained valid and all of the genetic components, including those for dominance, were significant (data not shown). Estimates of the parameters of the Hayman genetic analysis 


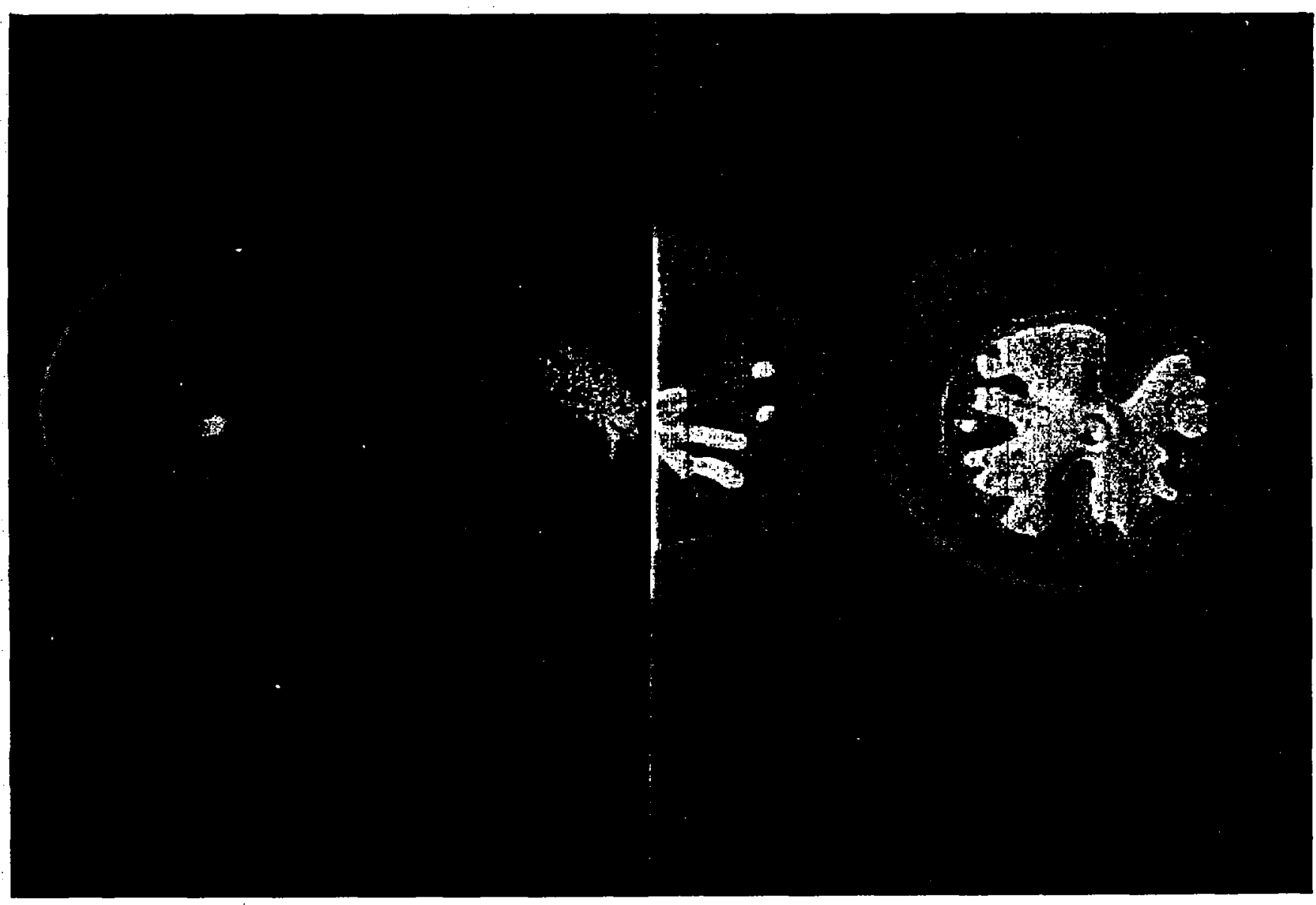

Fig. 2. Standard for rating blotch symptoms. Middle fruit has $\approx 25 \%$ blotchy tissue exposed; fruit with $>25 \%$ blotchy tissue, such as the one on the right, were classified as blotchy.

Table 1. Parameters of the Hayman and Griffing analyses $( \pm$ SE) of percent blotch in $9 \times 9$ diallels.

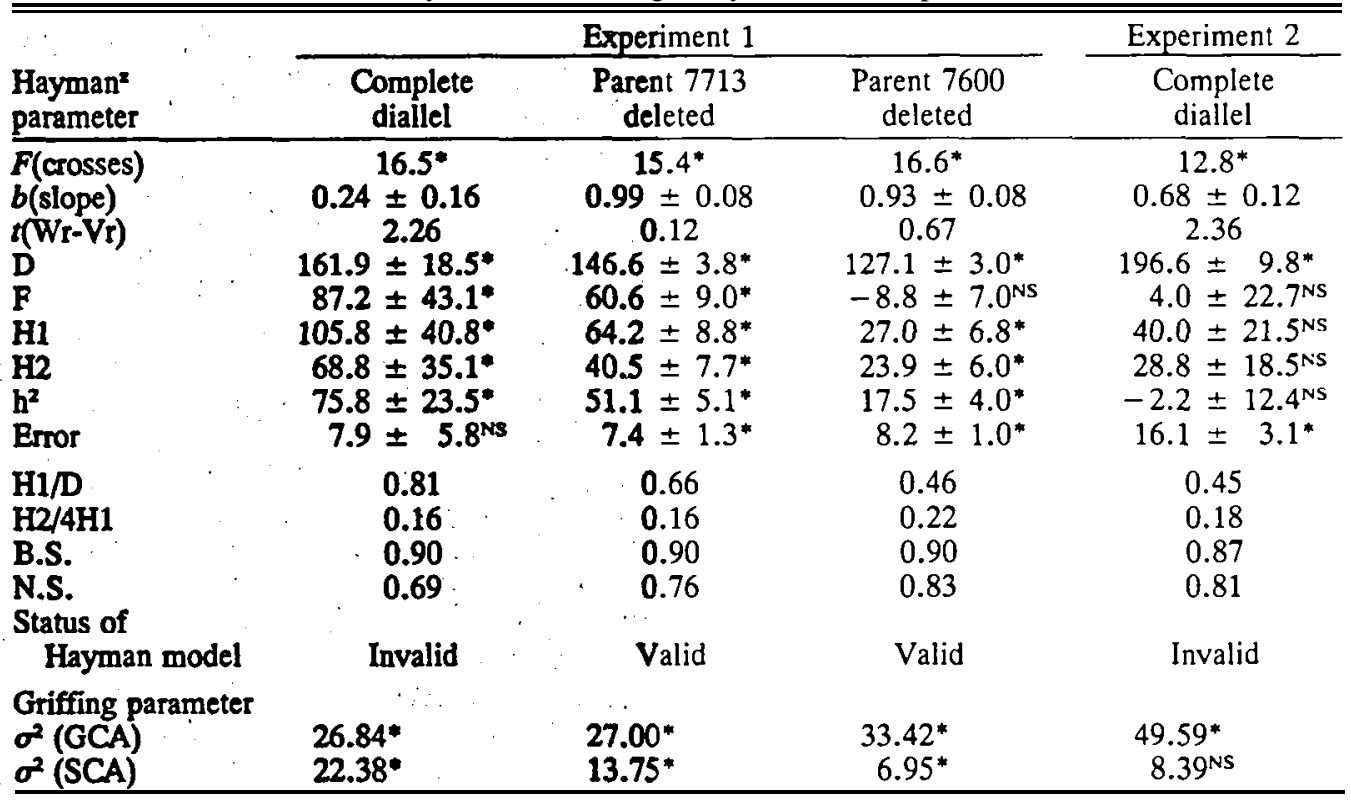

${ }_{\text {ZS }}^{\mathrm{z}}$ *yman, 1954.

NS, Nonsignificant or significant at $P=0.05$, respectively.

are shown in Table 1. The additive component of genetic variation (D) exceeded the dominance components ( $\mathrm{H} 1$ and $\mathrm{H} 2$ ) when either 7713 or 7600 was omitted. The mean degree of

J. Amer. Soc. Hort. Sci. 115(3):503-508. 1990. dominance (HI/D) resulting from the elimination of either 7713 or 7600 was 0.66 and 0.46 , respectively (Table 1), indicating partial dominance for blotch resistance. Broad-sense heritability

J. Amer. Soc. Hort. Sci. 115(3):503-508. 1990. 
Table 2. General (GCA) and specific (SCA) combining abilities and mean performance for parents and hybrids for percent blotch in Expt. 1.,

\begin{tabular}{|c|c|c|c|c|c|c|c|c|c|}
\hline Cultivar & 7223 & 7280 & 7600 & 7713 & 8430 & 8754 & C37A & C38 & H722. \\
\hline $\begin{array}{l}7223 \\
7280 \\
7600 \\
7713 \\
8430 \\
8754 \\
\text { C37A } \\
\text { C38 } \\
\text { H722 }\end{array}$ & $\begin{array}{r}-4.4 \\
27.9 \\
39.3 \\
43.5 \\
33.8 \\
37.8 \\
51.4 \\
37.7 \\
45.5\end{array}$ & $\begin{array}{r}-4.5 \\
-7.3 \\
42.1 \\
43.3 \\
27.5 \\
30.7 \\
44.0 \\
41.0 \\
41.5\end{array}$ & $\begin{array}{r}-3.9 \\
1.8 \\
3.5 \\
36.1 \\
36.1 \\
42.4 \\
51.3 \\
46.2 \\
51.8\end{array}$ & $\begin{array}{r}-2.1 \\
0.6 \\
-17.4 \\
5.9 \\
44.4 \\
44.4 \\
62.0 \\
46.6 \\
57.8\end{array}$ & $\begin{array}{r}0.5 \\
-3.0 \\
-5.2 \\
0.8 \\
-6.4 \\
34.6 \\
43.3 \\
38.5 \\
40.8\end{array}$ & $\begin{array}{r}0.6 \\
-3.6 \\
-2.6 \\
-3.1 \\
-0.6 \\
-2.5 \\
52.3 \\
43.2 \\
49.7\end{array}$ & $\begin{array}{r}5.3 \\
0.8 \\
-2.8 \\
5.5 \\
-0.8 \\
4.2 \\
6.4 \\
47.4 \\
51.4\end{array}$ & $\begin{array}{r}-1.6 \\
4.6 \\
-1.0 \\
-3.0 \\
1.2 \\
2.0 \\
-2.7 \\
-0.4 \\
44.3\end{array}$ & $\begin{array}{r}0.7 \\
-0.5 \\
-1.0 \\
2.7 \\
-2.1 \\
-3.0 \\
-4.3 \\
-4.5 \\
5.1 \\
\end{array}$ \\
\hline $\begin{array}{l}\text { Parent } \\
\text { mean }^{x}\end{array}$ & 37.7 & 31.4 & 67.2 & 63.9 & 35.9 & 39.2 & 54.3 & 45.9 & 57.3 \\
\hline
\end{tabular}

${ }^{\mathrm{z}} \mathrm{GCA}$ on diagonal, SCA above diagonal, mean performances of hybrid combinations below diagonal.

${ }^{\mathrm{y}} \mathrm{SE}$ for GCA are SCA and 0.6 and 1.8 , respectively.

${ }^{x} \mathrm{LSD}_{0.05}=6.4$.

Table 3. General (GCA) and specific (SCA) combining abilities and mean performance for parents and hybrids for percent blotch in Expt. 2.,y

\begin{tabular}{|c|c|c|c|c|c|c|c|c|c|}
\hline Cultivar & 6729 & 7223 & 7713 & 8430 & 8754 & H722 & $\mathrm{H} 2653$ & Ohio 7814 & ST64 \\
\hline $\begin{array}{l}6729 \\
7223 \\
7713 \\
8430 \\
8754 \\
\text { H722 } \\
\text { H2653 } \\
\text { Ohio 7814 } \\
\text { ST64 }\end{array}$ & $\begin{array}{l}-0.6 \\
53.6 \\
52.2 \\
35.2 \\
51.9 \\
48.0 \\
52.7 \\
44.3 \\
29.1\end{array}$ & $\begin{array}{l}2.0 \\
5.1 \\
54.2 \\
39.4 \\
49.9 \\
55.0 \\
62.3 \\
54.4 \\
47.6\end{array}$ & $\begin{array}{r}-0.3 \\
-3.9 \\
5.9 \\
36.8 \\
54.2 \\
50.2 \\
67.2 \\
53.8 \\
53.4\end{array}$ & $\begin{array}{r}0.6 \\
-0.8 \\
-4.3 \\
-11.9 \\
35.3 \\
38.4 \\
42.3 \\
34.0 \\
22.1\end{array}$ & $\begin{array}{r}4.4 \\
-3.1 \\
0.3 \\
-0.8 \\
0.9 \\
49.1 \\
62.7 \\
48.4 \\
42.5\end{array}$ & $\begin{array}{r}1.3 \\
2.6 \\
-3.0 \\
3.0 \\
1.0 \\
0.2 \\
49.2 \\
44.6 \\
37.2\end{array}$ & $\begin{array}{r}-4.8 \\
-0.8 \\
3.2 \\
-3.8 \\
3.8 \\
-9.0 \\
11.0 \\
57.1 \\
45.8\end{array}$ & $\begin{array}{r}-0.9 \\
3.6 \\
2.2 \\
0.2 \\
1.8 \\
-1.3 \\
0.4 \\
-1.4 \\
33.3\end{array}$ & $\begin{array}{r}-8.3 \\
4.6 \\
9.5 \\
-4.0 \\
3.6 \\
-1.0 \\
-3.1 \\
-3.3 \\
-9.1 \\
\end{array}$ \\
\hline Parent mean $x$ & 48.9 & 55.2 & 57.2 & 28.2 & 43.2 & 50.5 & 76.0 & 43.0 & $\overline{29.8}$ \\
\hline
\end{tabular}

-GCA on diagonal, SCA above diagonal, mean performances of hybrid combinations below diagonal.

ISE for GCA and SCA are 0.9 and 2.4 , respectively.

${ }^{L_{L S D}} \mathrm{D}_{0.05}=2.4$.

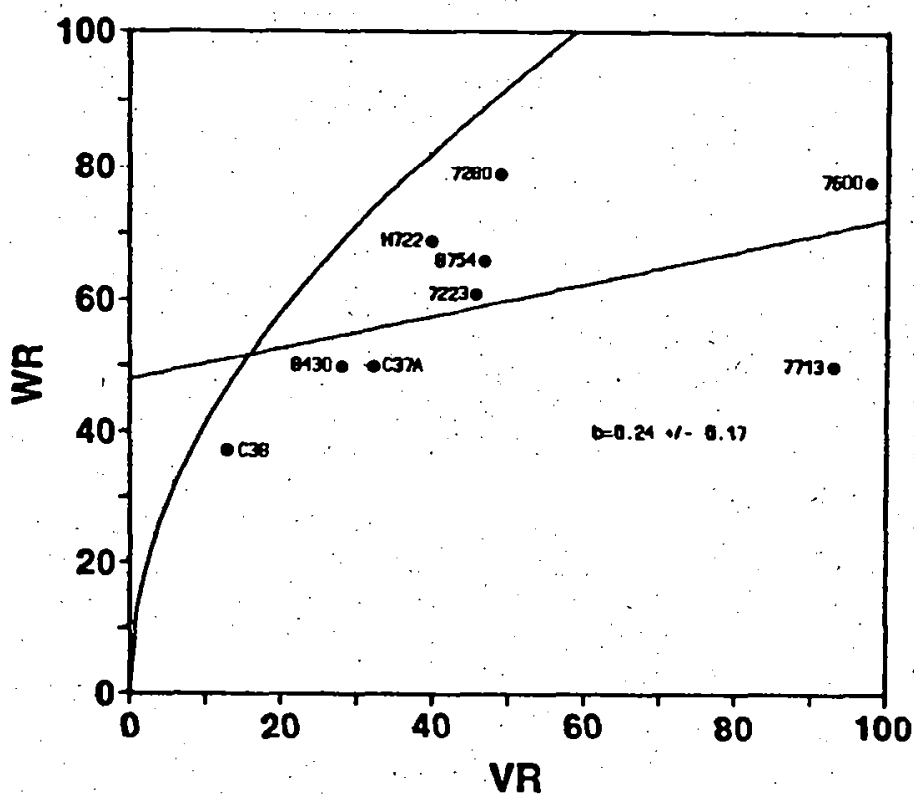

Fig. 3. Diallel graph for percent blotch in Expt. 1.

was calculated to be $90 \%$ and narrow-sense heritabilities were high in both cases. In the $\mathrm{Wr} / \mathrm{Vr}$ graph analysis, both 7713 and 7600 array members were farthest from the origin, showing that they had recessive alleles for influencing blotch (Figs. 4 and

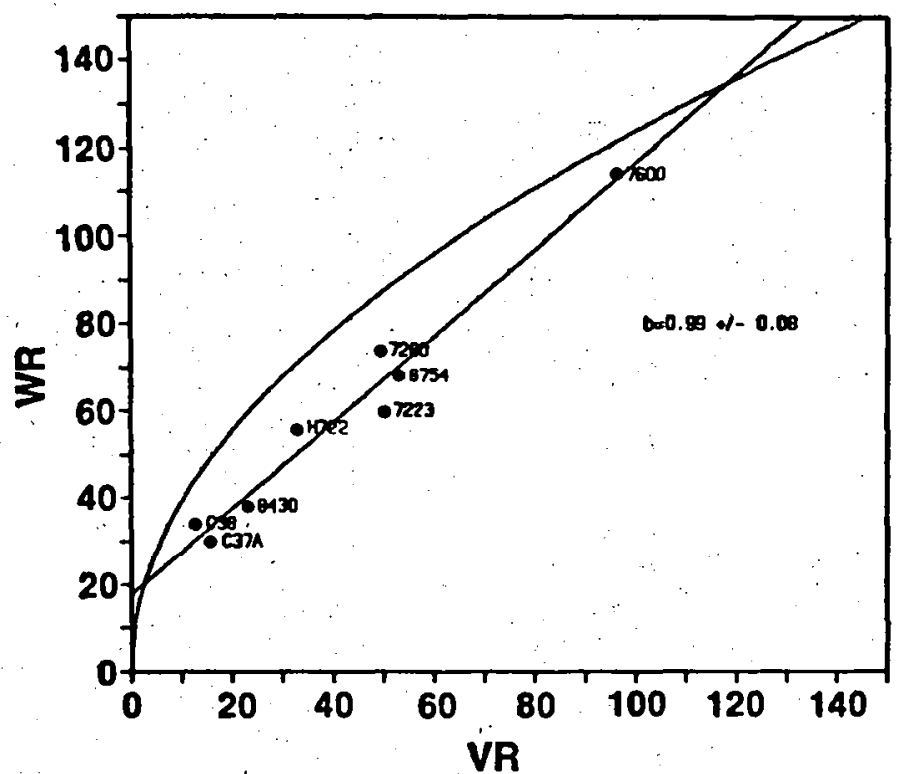

Fig. 4. Diallel graph for percent blotch in Expt. 1 with parent 7713 eliminated.

5). When 7713 was omitted from the analysis, C38, C37A, and 8430 had the most dominant alleles '(Fig. 4). When 7600 was omitted, only C38 appeared to have dominant alleles, with 8430, 


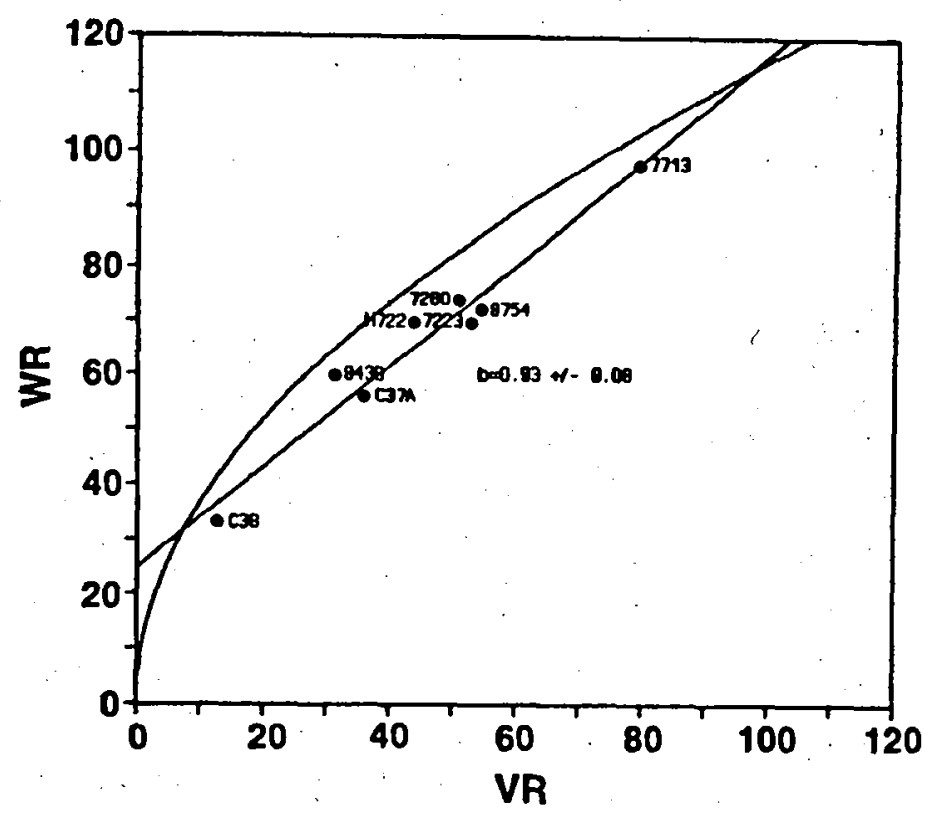

Fig. 5. Diallel graph for percent blotch in Expt. 1 with parent 7600 eliminated.

C37A, H722, 7280, 7223, and 8754 being intermediate (Fig. 5). The most susceptible genotypes, 7713 and 7600, had recessive alleles influencing blotch. The most blotch-resistant genotype, 7280, was not strongly affected by dominant gene action. However; lint C38, which was intermediate in blotch resistance, had a strong dominant genetic effect.

In the Griffing analysis, both GCA and SCA were significant, but a comparison of the variances for GCA and SCA indicated that GCA was much larger (Table 1). Both 7280 and 8430 had high GCA for resistance to blotch, while 7713, C37A, and H722 had high GCA for susceptibility (Table 2). The hybrid between the blotch-resistant lines 8430 and 7280 was not significantly $(P<0.05)$ different $(27.5 \%)$ than the most-resistant parent 7280 $(31.4 \%)$. The hybrid between the two blotch-susceptible lines $7713(63.9 \%)$ and $7600(67.2 \%)$ had significantly $(P<0.05)$ less blotchy fruit $(36.1 \%)$ than either parent (Table 2). GCA and SCA remained significant whether 7713 or 7600 was omitted from the analysis, but SCA was reduced more by the elimination of 7600 than 7713. The omission of both 7713 and 7600 from the analysis did not eliminate the significance of SCA (Table 1).

In Expt. 2, ANOVA indicated the absence of an interaction between genotype and the application of IL Hence, the replications were combined for further evaluation. In Hayman's analysis, a $\mathrm{Wr} / \mathrm{Vr}$ regression line of unit slope was not obtained. Removal of parents in various combinations failed to find a set that satisfied the requirements for a valid Hayman analysis. Nevertheless, the additive component, D, was large and significant, while the dominance components were not significant.

The Griffing analysis indicated the presence of significant variation due to additive gene effects; but not for dominant gene action (Table 1). Cultivars 8430 and ST64 had the highest GCA for blotch resistance, while H2653 exhibited the highest GCA for blotch susceptibility (Table 3).

The significance of genotype-environment $(\mathrm{G} \times \mathrm{E})$ interaction for blotch was determined by evaluating the performances of the five parents common to both Expts. 1 and 2 (7223, 7713, 8430, 8754, and H722) over 2 years (data not shown). The
$\mathrm{G} \times \mathrm{E}$ interaction was found to be highly significant. However, the mean square for entries in the diallel was significantly $(P$ $<0.01)$ greater than the mean square for $\mathrm{G} \times \mathrm{E}$ interaction. Except for 7223, the entries performed consistently between years. Blotch was least prevalent in 8430 and most prevalent in 7713.

\section{Discussion}

The diallel experiments revealed that the gene action for blotch resistance is mainly additive, although there is some dominance and epistasis present. A close association was observed between blotch resistance and GCA. Lines with high resistance to blotch tended to produce offspring with reduced amounts of blotchy fruit. Since GCA constitutes such a large component of the genetic variability for blotch, a recurrent selection program to develop cultivars with higher levels of resistance than demonstrated here should be effective. Epistasis was only important in the most blotch-susceptible lines. In these lines, susceptibility to blotch was conditioned by recessive genes. Selection for blotch resistance within $\mathrm{F}_{2}$ populations of the lines used in these experiments should be effective, provided that environmental variation within the plot area is low.

In Expt. 2, no parental combination could be found that would yield a $\mathrm{Wr} / \mathrm{Vr}$ regression line of unit slope. Therefore, according to Hayman's analysis, a simple additive-dominance model does not apply to this set of parents. However, the Griffing analysis found that SCA was not significant. This result indicates a lack of dominance that would cause a clustering of $\mathrm{Wr} / \mathrm{Vr}$ points in the Hayman analysis. In this case, a regression line with a slope of 1 would not likely be found. Mather and Poysa (1983) found that the mean square for dominance in the Hayman analysis was identical to the mean square for SCA in the Griffing analysis. Hence, when SCA is not significant in the Griffing analysis, dominance is not likely to be shown in the Hayman graphical analysis. Thus, Griffing analysis can be used to indicate when the Hayman analysis might be useful. As shown here, there is little reason to conduct the Hayman graphical analysis unless SCA is significant.

In a few hybrids, blotch resistance was equivalent to the better parent, but hybrids significantly superior to inbred lines within each experiment were not found. Selection for superior inbred lines should be more effective for improving blotch resistance than the development of hybrids. Nevertheless, when hybrids are required for purposes of earliness or disease resistance, the small amount of dominance for resistance to blotch found in some parents may prove advantageous, particularly in environments conducive to blotch.

Based on the diallel cross analysis of Expt. 1, the blotchsusceptible lines 7713 and 7600 exhibited epistatic gene action when crossed with each other. Fogelman (1966) similarly reported the presence of nonallelic gene interaction for blotch in an $F_{1}$ hybrid. Parent 7600 was the only line that possessed the recessive high pigment gene $(h p)$. In Nabisco lines, $h p$ has been associated with blotch in several different genetic backgrounds. Parent 7713 was also very susceptible to blotch and had a strong recessive genetic component according to the Hayman analysis. The interaction between genes at recessive loci may account for the epistasis observed in the hybrid.

To detect differences in blotch resistance, the experiments were conducted on soils with low levels of available K. Cultivars expressing resistance at low soil levels of $\mathrm{K}$ should maintain this resistance at the higher $\mathrm{K}$ levels $(200 \mathrm{ppm})$ that are required for processing tomatoes. A previous study (Dick and 
Shattuck, 1986) reported that blotch in the resistant cultivar 8430 could be reduced to $\approx 5 \%$ when grown on a Brookston silt loam soil supplemented with $500 \mathrm{~kg} \mathrm{~K} / \mathrm{ha}$. However, blotch in the susceptible 7713 cultivar under the same conditions was only reduced to $31 \%$.

In developing blotch-resistant cultivars, one must be sure that performance will be acceptable for the range of environmental conditions encountered in commercial production. In Expt. 2, in which $\mathrm{K}$ was applied to one-half of the replicates, no significant $\mathrm{G} \times \mathrm{E}$ interaction was found. However, significant $\mathrm{G} \times$ $\mathrm{E}$ interaction was found between Expts. 1 and 2, which were conducted in different years at different locations. This result might show a lack of consistency in expression of blotch resistance, except that the mean square for the entries in the diallel was significantly $(P<0.01)$ greater than the mean square for $\mathrm{G} \times \mathrm{E}$ interaction. According to LeClerg et al. (1962), this implies that some entries in the diallel were consistently superior to others. For cultivars common to both experiments (8430, 8754, H722, 7223, and 7713), 8430 was consistently rated most resistant to blotch, while 7713 was rated most susceptible. Relative variation in blotch among locations only occurred in cultivars with an intermediate level of resistance.

\section{Literature Cited}

Berry, J.W. 1966. Factors and practices related to the occurrence of blotchy ripening in tomato. PhD Diss., Michigan State Univ., East Lansing.

Besford, R.T. and G.A. Maw. 1975. Effect of potassium nutrition on tomato plant growth and fruit development. Plant \& Soil 42:395412.

Boyle, J.S. and E.L Bergman. 1967. Factors affecting incidence and severity of internal browning of tomato induced by tobacco mosaic virus. Phytopathology 57:354-362.

Canada Agricultural Products Standards Act. 1968. Ministry of Supply and Services, Can. Gov. Publishing Centre, Ottawa.

Chapman, H.D. and P.F. Pratt. 1961. Methods of analysis for soils, plants, and water. Div. of Agr. Sci., Univ. of California, Riverside.

Christie, B.R., V.I. Shattuck, and J.A. Dick. 1988. The diallel cross: Its analysis and interpretation. Office for Educational Practice, Univ. of Guelph, Guelph, Ont.

Dick, J.A. 1988. Breeding for resistance to blotchy ripening in processing tomatoes (Lycopersicon esculentum Mill.). PhD Diss., Univ. of Guelph, Guelph, Ont.

Dick, J. and V.I. Shattuck. 1986. Influence of potassium fertilization on blotchy ripening in processing tomatoes. Can. J. Plant Sci. 67:359363 .
Fogelman, M.E. 1966. A genetic and histological study of blotchy ripening in segregating generations of a tomato cross. PhD Diss., Iowa State Univ., Ames.

Griffing, B. 1956. Concept of general and specific combining ability in relation to diallel crossing systems. Austral. J. Biol. Sci. 9:463493.

Hayman, B.I. 1954. The theory and analysis of diallel crosses. Genetics 39:789-809.

Hobson, G.E. and J.N. Davies. 1977. A review of blotchy ripening and allied disorders of the tomato, 1957-1976. Glasshouse Crops Res. Inst. Annu. Rpt., Littlehampton, U.K. p. 137-147.

Hornby, C.A. and T. Matsumoto. 1974. Association of weather data and the incidence of blotchy ripening of greenhouse tomatoes in British Columbia. Can. J. Plant Sci. 54:123-127.

LeClerg, E., H. Leonard, A. Clark. 1962. Combined experiments. Field plot technique. 2nd ed. Burgess, Minneapolis. p. 215-234.

Lipton, W.J. 1970. Effects of high humidity and solar radiation on temperature and color of tomato fruits. J. Amer. Soc. Hort. Sci. 95:680-684.

Mather, D.E. and V.W. Poysa. 1983. Griffing and Hayman diallel analyses of protein and lysine content of spring triticale. Can. J. Genet. Cytol. 25:384-389.

Mather, K. and J.L. Jinks. 1982. Biometrical genetics: The study of continuous variation. 3rd ed. Chapman and Hall, London.

Minges, P.A. 1973. Further observation on occurrence and nature of blotchy ripening of tomatoes. HortScience 8:268.

Mokhtar, A.M., V.N. Lambeth, and O.P. Sehgal. 1982. Resistance to tobacco mosaic virus-induced blotchy ripening in greenhouse tomato hybrids. HortScience 17:934-936.

Ontario Ministry of Agriculture and Food. 1985. Vegetable production recommendations. Publ. 363. Queen's Printer for Ontario, Ont., Canada.

Picha, D.H. and C.B. Hall. 1981. Influence of potassium, cultivar, and season on tomato graywall and blotchy ripening. J. Amer. Soc. Hort. Sci. 106:704-708.

Smith, D.A., K.S. Rymal, J.L. Turner, and H. Harris. 1988. Thermal blast peeling of tomatoes. HortScience 23:185-186.

Steel, R.G.D. and J.H. Torrie. 1980. Principles and procedures of statistics, 2nd ed. McGraw-Hill, New York, p. 471-472.

Van der Boon, J. 1973. Influence of K/Ca ratio and drought on physiological disorders in tomato. Netherlands J. Agr. Sci. 21:56-67.

White, H.L. 1938. Further observations of the incidence of blotchy ripening of the tomato. Ann. Applied Biol. 25:544-557.

Widders, I.E. and O.A. Lorenz. 1982. Potassium nutrition during tomato plant development. J. Amer. Soc. Hort. Sci. 107:960-964.

Winsor, G.W. and M.I.E. Long. 1967. The effects of nitrogen, phosphorus, Potassium, magnesium and lime in factorial combination on ripening disorders of glasshouse tomatoes. J. Hort. Sci. 42:391402. 